\title{
THE SCIENTIFIC LITERACY PERFORMANCE OF GIFTED YOUNG SCIENTIST CANDIDATES IN THE DIGITAL AGE
}

\author{
Muhammad Mifta Fausan ${ }^{1,2}$, Herawati Susilo ${ }^{1 *}$, Abdul Gofur ${ }^{1}$, Sueb $^{1}$, Farrah Dina Yusop ${ }^{3}$ \\ ${ }^{1}$ Universitas Negeri Malang, Indonesia \\ ${ }^{2}$ Universitas Sulawesi Barat, Indonesia \\ ${ }^{3}$ Universiti Malaya, Malaysia \\ *e-mail: herawati.susilo.fmipa@um.ac.id
}

\begin{abstract}
Scientific Literacy (SL) is an important competency to deal with and keep up with the increasingly sophisticated technological developments. However, information about the SL of prospective gifted young scientists over 15 years old has not been widely revealed holistically. Therefore, this survey research aimed to investigate the SL performance of prospective gifted young scientists holistically and compare the SL performance based on the grade level. A total of 278 students from a public senior high school in Jombang Regency, East Java Province, Indonesia, participated in this research. They were asked to take the SL test with 18 essential question items. As a result, the participants still showed low SL performance (total success rate $=40$ ). The one-way ANOVA test results indicated no significant difference in the participants' SL performance based on the grade level. Therefore, three recommendations were provided: teachers should use various learning models, SL should be an explicit focus in science and non-science classrooms, and schools need to be equipped with supporting facilities to accommodate student readiness to practice SL.
\end{abstract}

Keywords: digital age, prospective gifted young scientist, scientific literacy.

\section{KINERJA LITERASI SAINS CALON ILMUWAN MUDA BERBAKAT DI ERA DIGITAL}

\begin{abstract}
Abstrak: Literasi Sains (LS) merupakan kompetensi penting untuk menghadapi sekaligus mengimbangi laju perkembangan teknologi yang semakin canggih. Namun, informasi tentang LS calon ilmuwan muda berbakat di atas usia 15 tahun belum banyak terungkap secara holistik. Oleh karenanya, penelitian survei ini bertujuan untuk menginvestigasi kinerja LS calon ilmuwan muda berbakat secara holistik dan membandingkan kinerja LS mereka berdasarkan tingkatan kelas. Sebanyak 278 siswa dari salah satu SMA negeri di Jombang, Provinsi Jawa Timur, Indonesia, berpartisipasi dalam penelitian ini. Mereka diminta untuk menyelesaikan tes LS yang berjumlah 18 item pertanyaan esensial. Hasil penelitian menunjukkan bahwa kinerja LS para peserta masih rendah (tingkat keberhasilan total $=40$ ). Hasil tes ANOVA satu arah menunjukkan bahwa tidak ada perbedaan signifikan kinerja LS peserta berdasarkan tingkat kelas. Untuk itu, diuusulkan tiga rekomendasi, yaitu guru harus menggunakan model pembelajaran yang bervariasi, LS harus mendapatkan perhatian yang lebih eksplisit di kelas sains dan non-sains, dan sekolah perlu dilengkapi dengan fasilitas pendukung untuk menunjang kesiapan siswa dalam praktik LS.
\end{abstract}

Kata Kunci: era digital, calon ilmuwan muda berbakat, literasi sains.

\section{INTRODUCTION}

The ease of accessing information in the digital era must be accompanied by competencies, such as good skills, attitudes, values, and knowledge (Napal, Mendióroz-Lacambra, \& Peñalva, 2020). These competencies are expected to anticipate the negative impact of the increasing number of fake news circulating through social networking sites, such as
Facebook, Twitter, Youtube, and WhatsApp. Fake news is made up and manipulated to look like a credible journalistic report designed to deceive readers (Brennen, 2017).

A critical competency for students to deal with and keep up with the increasingly sophisticated technological development is scientific literacy (Okada, 2013). Scientific literacy has many definitions because it is a 
broad subject with a very long history. OECD (2013) defines scientific literacy as one's ability to engage with scientific issues and ideas as a reflective citizen. Scientific literacy is also defined as understanding scientific concepts meaningfully, explaining scientific phenomena, describing them based on scientific evidence, and applying them in everyday life (Fives, Huebner, Birnbaum, \& Nicolich, 2014).

Scientific literacy emphasizes the science concept, the nature of science, and the interaction between science and society (Archer-Bradshaw, 2014). The science concept is necessary because it functions to understand science and the main asset in problem-solving. The nature of science is the epistemology of science, conceptualized as the value and belief in science, allowing students to understand that evidence can build scientific knowledge. The interaction between science \& society can be achieved if students are taught from a social perspective, study science under what they see, and apply it in social lives. Kähler, Hahn, \& Köller (2020) also stated that these three components allow one to face scientific situations, and actively participate in societies where science and technology are very important.

Scientific literacy is essential to be promoted both in science and non-science classes. Gu, Wang, \& Lin (2019) stated that scientific literacy cannot be ignored and must always be explored to students, as it helps them make the right decisions (Lederman, Lederman, \& Antink, 2013), solve individual and universal problems (Choi, Lee, Shin, Kim, \& Krajcik, 2011), and achieve the goals of science learning (Fakhriyah, Masfuah, Roysa, Rusilowati, \& Rahayu, 2017). When someone has adequate scientific literacy obtaining information, he/ she will use the scientific principles to check the validity of information sources, understand and explain phenomena that occur scientifically, interpret the data obtained, make conclusions based on credible data, and design the right solution.

Scientific literacy is correlated with information literacy (intellectual framework for understanding, discovering, evaluating, and using information). Podgornik, Dolničar, \& Glažar (2017) found a significant positive correlation between scientific literacy and information literacy, where one's information literacy depends on his/her scientific literacy. Therefore, as one of the core competencies in the 21st century (UNEP, 2012), scientific literacy plays an essential role for every citizen to access, read, and understand the world with scientific and technological dimensions (DeBoer, 2000).

In the context of science learning in Indonesian high schools, scientific literacy is the highest achievement of the science education process (Kemendikbud RoI, 2017). In Indonesia's 2013 Curriculum, scientific literacy development has been accommodated, especially in all science subjects (biology, physics, and chemistry) because the approach orientation in the Curriculum is the scientific approach (for example, through observing, asking questions, gathering information, associating or analyzing, and communicating) and achieving balanced competences between attitudes, knowledge, and skills. In fact, science learning process and evaluation in several high schools have not maximally empowered students' scientific literacy (Nainggolan, Situmorang, \& Hastuti, 2021; Pratiwi, Cari, \& Aminah, 2019). This condition is in line with the results of our initial survey observations in a public senior high school in Jombang Regency, East Java, Indonesia. Empirical facts were found, including science learning process in science and nonscience classes that still emphasized expository learning (tends to concept memorization activities), only a few learning activities that provide opportunities for students (individuals and groups) to play an active role in constructing their scientific concepts, and scientific processes such as practicum activities to prove the theory that is also rarely done.

Another empirical fact is that the evaluation questions used by teachers tend to be less contextual and dominant only measure the dimension of the cognitive process level 1-3. Only $20 \%$ of the evaluation questions measure cognitive level 4 and above (critical thinking domain). In contrast, according to Yore, Pimm, \& Tuan (2007), critical thinking is one of the fundamental components of scientific literacy. Therefore, it is necessary to introduce an evaluation instrument model that can be used to assess students' scientific literacy at the senior high school level. One suitable instrument is the Test of Scientific Literacy Skills (ToSLS). ToSLS could assess overall scientific literacy in student 
populations and find out potential differences in scientific literacy based on student demographic (Shaffer, Ferguson, \& Denaro, 2019). ToSLS developed by Gormally, Brickman, \& Lut (2012) with nine indicators, including 1) identifying valid scientific arguments. 2) evaluating source validity. 3) evaluating the use and misuse of scientific information. 4) understanding the elements of research design and their effect on scientific conclusions. 5) creating a graphical representation of data. 6) reading and interpreting graphical representations of data. 7) solving problems using quantitative skills. 8) understanding and interpreting basic statistics. 9) validating inferences, predictions, and conclusions based on quantitative data. Based on all empirical facts from the results of preliminary observations, it is the rationale for selecting the object of our survey research.

Despite the importance of scientific literacy and empirical facts, information about students' scientific literacy over 15 years has not been widely revealed, and there are still few studies in Indonesia that reveal scientific literacy based on grade levels and its effect holistically. Most of the previous research (Fadilah, Isti, Wida, Amarta, \& Prabowo, 2020; Huryah, Sumarmin, \& Effendi, 2017; Natalina \& Suryawati, 2019; Rahmadani, Fitakurahmah, Fungky, Prihatin, Majid, \& Prayitno, 2018) only revealed the scientific literacy profile of high school students in several cities in Indonesia. Therefore, it is important to be further explored because it describes the students' scientific literacy success rate in each grade. Furthermore, the data serve as the basis for making the right policies to create better science learning.

The testing of grade levels' effect on scientific literacy performance of students aims to test statistical differences based on grade level variables. This testing is crucial to determine whether there is a need to promote scientific literacy at the lower grade level or even at each grade level. Therefore, this research aims to investigate scientific literacy's performance holistically at various grade levels of gifted young scientist candidates in a public senior high school. It also compares scientific literacy performance based on grade level in a public senior high school.

\section{METHODS \\ Research Type}

This research is descriptive used a quantitative approach. Descriptive analysis was chosen because it can accurately describe an individual's characteristics, situation, or group (Kothari, 2004). The data were collected using the exploratory survey method. This method was chosen because it is an important tool for gathering information about individuals' perspectives in large groups. On the other hand, the survey also has several advantages, including visual aids, complex questions, and higher response rates (Jones, Baxter, \& Khanduja, 2013).

\section{Participants}

Gifted young scientist candidates who became participants in this research are students in the science course interest group in science classes and non-science classes, in a public senior high school in Jombang Regency, East Java Province, Indonesia. The total population was 822 students. Using a systematic random sampling design (Leedy \& Ormrod, 2019), a number of 278 students was assigned as the research sample. In detail, the sample grade $\mathrm{X}$ consisted of 95 students (science class: 48 students, non-science class: 47 students); the sample grade XI consisted of 91 students (science class: 46 students, non-science class: 45 students); the sample grade XII consisted of 92 students (science class: 46 students, non-science class: 46 students).

\section{Instrument and Procedures}

The research instrument was the Test of Scientific Literacy Skills (ToSLS), adapted from an instrument developed by Gormally, Brickman, \& Lut (2012). This instrument was used because it contains essential scientific literacy with indicators and guidelines in developing the question items. This instrument was thought to be sufficient for data collection, because it focused more on describing the implementation of scientific information and methods when solving everyday life problems, instead of testing students' specific knowledge about science subjects. The ToSLS instrument consists of nine indicators, as shown in Table 1. 
Table 1. Indicators and the Number of Scientific Literacy Questions

\begin{tabular}{lc}
\hline No. Scientific Literacy Indicators & $\begin{array}{c}\text { Number of } \\
\text { Questions }\end{array}$ \\
\hline 1. Identifying valid scientific arguments & 3 \\
2. Evaluating source validity & 1 \\
3. Evaluating the use and misuse of scientific information & 2 \\
4. Understanding the elements of research design and their effect on scientific & 2 \\
conclusions & 1 \\
5. Creating a graphical representation of data & 4 \\
6. Reading and interpreting graphical representations of data & 2 \\
7. Solving problems using quantitative skills & 2 \\
8. Understanding and interpreting basic statistics & 1 \\
9. Validating inferences, predictions, and conclusions based on quantitative data & \\
\hline
\end{tabular}

Experts in education and science first corrected the instruments used in this study. After being declared feasible, a paper-based test was conducted on 32 students randomly selected from grades X, XI, and XII (science and nonscience classes). This testing aims to ensure that each item has good validity and reliability. Before testing the validity of the items, we first tested the normality using the ShapiroWilk test; the result was $p$-value $.065>.05$ (normally distributed). Furthermore, the validity of test items was performed using the Pearson correlation and reliability using Cronbach's Alpha. Of the 20 items tested, 18 items were valid and reliable. The average validity of the 18 items was .546, and the reliability was .863 .

Before working on the ToSLS, participants had to fill in their identities (full name, student identification number, grade, and gender). ToSLS consisted of 18 multiple-choice questions to be completed by the participants in 35 minutes. The ToSLS items were divided into nine indicators, as described in Table 1. Participants were not allowed to use any assistive devices while completing the test (for example, calculator, mobile phone, and tablet). They answered the questions by choosing one answer considered the most correct from the five answer choices. If the participant chooses the correct answer, they get a score of 1 ; if they answer incorrectly or do not answer, they get 0 . Table 2 presents a sample question used to measure the first scientific literacy indicator (identifying valid scientific arguments).

\section{Table 2. Sample Question of Scientific Literacy}

\begin{tabular}{|c|c|}
\hline Question & Answer Choices \\
\hline \multirow{5}{*}{$\begin{array}{l}\text { Some salespersons from companies that } \\
\text { produce sports equipment are assigned to } \\
\text { promote a weight training tool (barbells) on } \\
\text { a YouTube channel. They claim that their } \\
\text { product can give "tremendous power". Which } \\
\text { of the following statements will provide the } \\
\text { strongest evidence of the effectiveness of } \\
\text { barbells for increasing muscle strength? }\end{array}$} & $\begin{array}{l}\text { a. Barbell users can lift significantly heavier weights } \\
\text { after two months of training. }\end{array}$ \\
\hline & $\begin{array}{l}\text { b. The survey data show that barbell users report } \\
\text { significantly greater muscle tone. }\end{array}$ \\
\hline & $\begin{array}{l}\text { c. The survey data show that the average barbell users } \\
\text { can exercise six times a week. }\end{array}$ \\
\hline & $\begin{array}{l}\text { d. Barbell users experience a } 100 \% \text { increase in blood } \\
\text { flow to their muscles. }\end{array}$ \\
\hline & e. The barbell can increase the blood flow in their body. \\
\hline
\end{tabular}




\section{Data Analysis}

The data obtained were analyzed descriptively and inferentially. Descriptive statistics were used to obtain the mean and standard deviation of the data. The descriptive analysis results could provide an overview of gifted young scientist candidates' scientific literacy at each grade level. Jufrida, Basuki, Kurniawan, Pangestu, \& Fitaloka (2019) stated that the score criteria for each measured indicator of scientific literacy are 81-100 (very high), 6180 (high), 41-60 (medium), 21-40 (low), and 0-20 (very low).

Inferential statistics were used to compare scientific literacy performance based on grade level. The inferential statistic used the one-way analysis of variance (One-Way ANOVA). Before the ANOVA test, prerequisite tests, namely the normality, homogeneity, and linearity tests, were first performed. The Kolmogorov-Smirnov test was used to test normality, Levene's test was used to test homogeneity, and the ANOVA test was used to test linearity. The prerequisite tests' guidelines for decision-making are if the significant value is greater than the confidence level $(\dot{\alpha}=.05)$. The data is considered normal, comes from a population with the same variant, and linear between variables. The data from all inferential statistical tests (prerequisite and hypothesis tests) were processed using statistical software.

\section{RESULTS AND DISCUSSION \\ Results \\ Scientific Literacy Performance of Gifted Young Scientist Candidates}

The success rate of Scientific Literacy performance of gifted young scientist candidates is presented in detail in Table 3. Table 3 shows that overall, the mean score of gifted young scientists' scientific literacy performance still tends to be a low category. It can be seen from the low achievement of each measured scientific literacy indicator. Scientific literacy indicators 1 , $5,7,8$, and 9 are in a low category. Indicators 3 , 4 , and 6 are in the medium category, and it seems that these indicators have a similar difference in mean. Although most scientific literacy indicators are low, and three are medium, one scientific literacy indicator is in the high category, namely indicator 2 (evaluating source validity) with a mean of 62 . The percentage of participants in each category is presented in Table 4.

Table 3. The Success Rate of the Participants' Scientific Literacy Performance

\begin{tabular}{lcccccc}
\hline \multirow{2}{*}{ Scientific Literacy (SL) indicators } & \multicolumn{3}{c}{ Grade } & \multicolumn{2}{c}{ SL Success } & \multirow{2}{*}{ Category } \\
\cline { 2 - 4 } & X & XI & XII & Rate & \\
\hline 1. Identifying valid scientific arguments & 39 & 39 & 36 & & 38 & Low \\
2. Evaluating source validity & 64 & 62 & 60 & 62 & High \\
3. Evaluating the use and misuse of scientific information & 38 & 51 & 48 & 46 & Medium \\
4. Understanding the elements of research design and their & 39 & 42 & 46 & 42 & Medium \\
$\quad$ effect on scientific conclusions & 44 & 40 & 34 & 39 & Low \\
5. Creating a graphical representation of data & 40 & 47 & 44 & 44 & Medium \\
6. Reading and interpreting graphical representations of data & 35 & 23 & 37 & 32 & Low \\
7. Solving problems using quantitative skills & 35 & 34 & 32 & 34 & Low \\
8. Understanding and interpreting basic statistics & 39 & 14 & 22 & 25 & Low \\
9. Validating inferences, predictions, and conclusions based & & & & & & \\
$\quad$ on quantitative data & & & & & Low \\
\hline Total success rate &
\end{tabular}

Table 4. The Percentage of Participants in each Category

\begin{tabular}{lccccc}
\hline \multirow{2}{*}{ Grade Level } & \multicolumn{5}{c}{ Percentage of Participants in each Category } \\
\cline { 2 - 6 } & Very low & Low & Medium & High & Very high \\
\hline X & 8 & 47 & 34 & 11 & 0 \\
XI & 5 & 51 & 35 & 9 & 0 \\
XII & 7 & 47 & 34 & 12 & 0 \\
\hline
\end{tabular}


Table 4 shows that the percentage of participants at each level is still dominant in the low category. The high category rate is almost identical at each grade level, from grade $\mathrm{X}$, grade $\mathrm{XI}$, to grade XII $(11,9,12$, respectively). The data in Table 4 also shows that no participants have very high scientific literacy performance. The summary of descriptive statistics of gifted young scientist candidates' scientific literacy performance by grade level is presented in Table 5.

Table 5. The Summary of the Descriptive Statistic of the Participants' Scientific Literacy Performance by Grade Level

\begin{tabular}{llccc}
\hline $\begin{array}{c}\text { Grade } \\
\text { Level }\end{array}$ & Gender & $\boldsymbol{N}$ & Mean & $\begin{array}{c}\text { Std. } \\
\text { Deviation }\end{array}$ \\
\hline $\mathrm{X}$ & Male & 32 & 39.19 & 14.63 \\
& Female & 63 & 40.30 & 13.84 \\
& Total & 95 & 39.93 & 14.04 \\
XI & Male & 35 & 37.03 & 10.65 \\
& Female & 56 & 41.59 & 13.81 \\
& Total & 91 & 39.84 & 12.82 \\
XII & Male & 25 & 38.64 & 16.57 \\
& Female & 67 & 41.03 & 13.33 \\
& Total & 92 & 40.38 & 14.23 \\
Total & Male & 92 & 38.22 & 13.73 \\
& Female & 186 & 40.95 & 13.58 \\
& Total & 278 & 40.05 & 13.67 \\
\hline
\end{tabular}

Table 5 shows that the total means and standard deviations of grades X, XI, and XII are $39.93 \pm 14.04,39.84 \pm 12.82$, and $40.38 \pm 14.23$, respectively. Viewed from the total mean of each level, if rounded off, the total mean is 40 , with a standard deviation of 13.67. Therefore, these data also inform that the total mean of scientific literacy performance of gifted young scientist candidates at each level is almost identical.

\section{The Comparison of Scientific Literacy Performance of Gifted Young Scientist Candidates based on Grade Level}

Before the empirical test using OneWay ANOVA, prerequisite tests for normality, homogeneity, and linearity were conducted. Firstly, the Kolmogorov-Smirnov test results show the $p$-values of each class X, XI, and XII, respectively, of $.093, .070, .109>.05$. These values indicate that the samples were obtained from a normally distributed population. Second, Levene's test results show a $p$-value of $.565>$ .05 . This value indicates that the samples were obtained from a homogeneous population. Third, the ANOVA test results show the deviation from linearity value of $.856>.05$. Therefore, it can be concluded that there is a significant linear relationship between the grade level variable and the score variable.

Based on the prerequisite test results, hypothesis testing was conducted using the OneWay ANOVA test. A summary of the results of hypothesis testing is presented in Table 6 .

Table 6. The Summary of One-Way ANOVA Test Results

\begin{tabular}{lrrrrr}
\hline & $\begin{array}{c}\text { Sum of } \\
\text { Squares }\end{array}$ & $\boldsymbol{d f}$ & $\begin{array}{c}\text { Mean } \\
\text { Square }\end{array}$ & $\boldsymbol{F}$ & Sig. \\
\hline $\begin{array}{l}\text { Between } \\
\text { groups }\end{array}$ & 15.696 & 2 & 7.848 & .042 & .959 \\
$\begin{array}{l}\text { Within } \\
\text { groups }\end{array}$ & 51740.696 & 275 & 188.148 & & \\
\hline Total & 51756.392 & 277 & & & \\
\hline
\end{tabular}

Table 6 shows $p$-value $.959>.05$. Referring to the hypothesis formulated in this study, $\mathrm{H}_{0}$ (there is no difference in the scientific literacy performance among gifted young scientist candidates in grades X, XI, and XII), and $H_{1}$ (there is a difference in the scientific literacy performance among gifted young scientist candidates in grades X, XI, and XII), so based on the $p$-value in Table 6 , it is concluded that the null hypothesis $\left(\mathrm{H}_{0}\right)$ is accepted and the alternative hypothesis $\left(\mathrm{H}_{1}\right)$ is rejected. Therefore, there is no significant difference in the scientific literacy performance of gifted young scientist candidates who are in grades X, XI, and XII.

\section{Discussion}

\section{Scientific Literacy Performance of Gifted Young Scientist Candidates}

This section discusses scientific literacy based on three categories, high (indicator 2), medium (indicators 3, 4, and 6), and low (indicators 1, 5, 7, 8, and 9). Firstly, indicator 2 is the only indicator in the high category. In this indicator, all participants were challenged 
to evaluate the validity of the sources presented. The results indicated that most of them could identify the problems of source accuracy and credibility. However, this indicator must still be considered and developed in the digital era, because the need for continuous information by many websites that report scientific information makes people tend to find misleading or inaccurate information, even from education and news websites (Chung, Oden, Joyner, Sims, \& Moon, 2012). Many people accept what they read or hear as scientific facts without thinking much and critically examining the details (Fausan, Susilo, Gofur, Sueb, \& Yusop, 2021).

Second, indicator 3 is one of the indicators already in the medium category. In this indicator, the participants were tested to evaluate the use and misuse of scientific information. The results showed that almost half of the participants could evaluate scientific information. This evaluation involves judging the acceptability of some information and some cognitive actions taken because of that assessment. In a world full of information sources and media, one must also gain an accurate understanding of how scientific knowledge arises to interpret scientific information correctly (Britt, Richter, \& Rouet, 2014).

Like indicator 3 , indicators 4 and 6 are already in the medium category. These findings inform us that some respondents have begun understanding the basic research design elements (indicator 4). On the other hand, we found a unique fact, that respondents were more successful in solving problems related to interpreting and reading graphic information (indicator 6) than making correct graphs of the data presented (indicator 5), even though these two indicators are considered closely related. The ability of indicator 6 is very relevant amid the current Covid-19 pandemic, where the ability to read graphic information presented by government authorities is important to see the development of confirmed positive case trends. Furthermore, indicator 4 has an essential role as an overview of the research procedure conceptual structure. Sekaran (2003) stated that research design is made to determine how to collect data further, analyze and interpret it, and ultimately answer the problems.

Third, in indicator 1, identifying valid scientific arguments, participants seemed to have problems linking true claims with facts or irrelevant evidence that is considered to support a scientific argument. The low level of success in indicator one is reflected in the use of the learning model by teachers in the science teaching and learning process. We observed that in the science learning process in both science and non-science classrooms, teachers still maintain traditional learning, which is considered easier. Consequently, it only presents learning facts, not trained students to identify and correct scientific arguments. In fact, one of the essential aspects of one's thinking ability to succeed in life is argumentation ability (Indrawatiningsih, Purwanto, Rahman, \& Sa'dijah, 2020). Therefore, identifying valid scientific arguments is essential because it is also used as a tool to prove or justify a scientific conclusion (Osborne, Jonathan, \& Patterson, 2011).

In indicator 5, creating a graphical representation of the data, participants seemed to have problems determining the most suitable graphical form for the given data. The low scientific literacy performance in this indicator may also be influenced by the fact that drawing graphics is only measured by one test item. Regardless of this possibility, low indicator 5 indicated that most participants do not understand statistical graphs or cannot apply their knowledge of graphs to find solutions to problems. Dodge (2008) revealed that graphical representation includes various techniques for clarifying, interpreting, and analyzing data by drawing line segments or plotting points in a graph. Graphs are used to visualize the data set quickly; therefore, the student's abilities to create graphical representations must be continuously developed to present their data correctly.

The low achievement in indicators 7 and 8 indicated that participants have low selfefficacy, because they only guess the correct answer without explaining the necessary math calculations. They are also considered to have limited knowledge about statistical functions and scientific uncertainties. Solving problems using quantitative skills (indicator 7) requires special attention in science learning. These skills are also less empowered in the science and non-science classes observed; thus, students have limitations in exploring solutions and problem-solving plans related to arithmetic. Metz (2008) stated that empowering quantitative 
skills in science learning, has also been reported to improve students' ability to make crucial connections between statistical concepts and their application to scientific data analysis. It implies that earlier introducing and facilitating students to quantitative skills and problemsolving in science is considered essential for preparing future professional candidates (Goldstein \& Flynn, 2011).

Furthermore, basic statistical skills (indicator 8) are essential for communicating the results and credibility of scientific procedures and conclusions. Glazer (2011) specifically stated that interpreting graphs and applying statistical analysis to experimental results are important for developing scientific literacy. Therefore, teaching students about the correct data collection, analysis and representation, probability, conclusion, and interpretation of results is crucial in science learning.

Indicator 9 has the lowest mean of all measured scientific literacy indicators. It indicates that most participants drew a wrong scientific conclusion from the data presented and incorrectly predicted the data. Participants' tendency to make mistakes in interpreting a lot might be due to ignoring graphic data, when developing a hypothesis or evaluating an argument. To succeed in this ninth indicator, according to Čipková, Karolčík, \& Scholzová (2019), students need to summarize and generalize the information obtained to conclude.

The scientific literacy performance of gifted young scientist candidates is mostly in the low category. The results of this research are in line with the previous study, also revealing the students' low scientific literacy performance on each measured indicator (Čipková et al., 2019; Novaristiana, Rinanto, \& Ramli, 2019). The low performance can be caused by passive learning because it does not facilitate or direct them in good problem-solving planning (Bellová, Melicherčíková, \& Tomčík, 2017). Therefore, teachers should focus on content knowledge as well as procedural and epistemic knowledge. Teachers who play a significant role in student education, such as facilitators and mentors of students in the class, need to prepare themselves and be positive in every curriculum transformation, one of which is thinking about how to teach scientific literacy strategies to their students well.
Kumar \& Banerjee (2018) reported critical areas for improving students' functional scientific literacy performance by using appropriate teaching strategies. Using learning strategies and providing students with relevant learning experiences were also reported to determine their learning success (Wicaksono, Susilo, \& Sueb, 2019). Learning strategies (sometimes called learning model) that are reported to improve students' scientific literacy performance include Guided Inquiry (Ristanto, Zubaidah, Amin, \& Rohman, 2017), ProjectBased Learning (Winarni \& Purwandari, 2020), and PBL-Based Socio-Scientific Issues (Hestiana \& Rosana, 2020). These strategies provide real experiences and an authentic environment that enable students to proceed in learning.

Designing quality learning that empowers scientific literacy requires a continuous process. Therefore, it is deemed necessary to improve the quality of teaching through collaborative activities between teachers in constructive teaching (for example, observing \& discussing, evaluating, and developing), one of which is through lesson study. Lesson study is conducted to foster teachers' competence and collegiality. It also encourages better practice and learning outcomes (Hasan, Lukitasari, Utami, \& Anizar, 2019).

\section{The Comparison of Scientific Literacy Performance of Gifted Young Scientist Candidates based on Grade Level}

The parametric statistical test results using the One-Way ANOVA test, indicated no significant difference in the scientific literacy performance among gifted young scientist candidates in grades X, XI, and XII ( $p$-value $=.959>.05)$. This results in line with Genç (2015), who reported no significant difference in students' scientific literacy by class level $(p=.696)$. These results indicate that research on scientific literacy can be carried out independently of grade-level variables. This research also confirms that scientific literacy must continue to be empowered or promoted at various grade levels.

Liu (2009) reported several rational reasons for the importance of promoting scientific literacy, including 1) providing experiences for developing language, logic, and problem-solving skills in class. 2) plays a fundamental role and 
requires scientific knowledge and understanding of the scientific methodology. 3) supports economic competitiveness and national needs. Furthermore, scientific literacy forms the basis for studying many other disciplines (Blyznyuk, 2019), so students with good scientific literacy have a great opportunity to be involved in a productive career (Yuenyong, 2013).

Scientific literacy is one of the topics in science education capable of dealing with technological developments, such as answering hoaxes about science and technology (Widayoko, Femilia, Lesmono, Sudjatmi, Prastiwi, \& Munfarikha, 2019). Various information, either true or false, is accessible every day. Without adequate knowledge and critical information, someone will easily trust any information, including scientific information. Therefore, scientific literacy is needed to filter it.

\section{CONCLUSION}

Based on the results and discussion, it is concluded that the scientific literacy performance of gifted young scientist candidates is still a low category. At the same time, this finding confirms that the current pattern of science learning in high schools is considered less capable of empowering or still lacking in promoting scientific literacy to gifted young scientist candidates. Besides, this research revealed no significant difference in the scientific literacy performance among gifted young scientist candidates in grades X, XI, and XII in a public senior high school. Scientific literacy in this digital era must continue to be empowered or promoted at various grade levels.

From the results of this research, the authors propose three recommendations. First, teachers should use learning strategies that will be proven to empower scientific literacy in the classroom. These include guided inquiry, Problem-Based Learning (PBL), and Project-Based Learning (PjBL). Second, scientific literacy should be an explicit focus and be implemented in science and non-science classrooms because it is intended for all students. The authors agree with suggestions made by Sharma \& Sharma (2017) that although students do not have a career in science, the skills they develop when studying science can be helpful in other aspects of their lives. Finally, the school need to be equipped with supporting facilities and infrastructure to support students' readiness to practice scientific literacy.

\section{ACKNOWLEDGMENT}

The authors would like to thank the Rector of Universitas Negeri Malang, who has fully funded this research through the Dissertation Research Competitive scheme with PNBP funding sources for the 2020 fiscal year. Rector's Decree Number: 3.3.16/UN32/KP/2020.

\section{REFERENCES}

Archer-Bradshaw, R. E. (2014). Demystifying scientific literacy: Charting the path for the 21 st century. Journal of Educational and Social Research, 4(3), 165-172. https:// doi.org/10.5901/jesr.2014.v4n3p165.

Bellová, R., Melicherčíková, D., \& Tomčík, P. (2017). Possible reasons for low scientific literacy of Slovak students in some natural science subjects in some natural science subjects. Research in Science \& Technological Education, 36(2), 226242. https://doi.org/10.1080/02635143.20 17.1367656.

Blyznyuk, T. (2019). Defining and conceptualizing geocultural scientific literacy. Journal of Vasyl Stefanyk Precarpathian National University, 6(1), 43-49. https://doi.org/10.15330/ jpnu.6.1.43-49.

Brennen, B. (2017). Making sense of lies, deceptive propaganda, and fake news. Journal of Media Ethics, 32(3), 179-181. https://doi.org/10.1080/23736992.2017.1 331023 .

Britt, M. A., Richter, T., \& Rouet, J. F. (2014). Scientific literacy: The role of goaldirected reading and evaluation in understanding scientific information. Educational Psychologist, 49(2), 104122. https://doi.org/10.1080/00461520.2 $\underline{014.916217 .}$.

Choi, K., Lee, H., Shin, N., Kim, S.-W., \& Krajcik, J. (2011). Re-conceptualization of scientific literacy in South Korea for the 21st century. Journal of Research in Science Teaching, 48(6), 670-697. https:// doi.org/10.1002/tea.20424. 
Chung, M., Oden, R. P., Joyner, B. L., Sims, A., \& Moon, R. Y. (2012). Safe infant sleep recommendations on the Internet: Let's google it. The Journal of Pediatrics, 161(6), 1080-1084. https://doi. org/10.1016/j.jpeds.2012.06.004.

Čipková, E., Karolčík, Š., \& Scholzová, L. (2019). Are secondary school graduates prepared for the studies of natural sciences? - evaluation and analysis of the result of scientific literacy levels achieved by secondary school graduates. Research in Science \& Technological Education, 38(2), 146-167. https://doi.org/10.1080/0 2635143.2019.1599846.

DeBoer, G. E. (2000). Scientific literacy another looks. Journal of Research in Science Teaching, 37(6), 582601. $\quad$ https://doi.org/10.1002/1098$2736(200008) 37: 6<582::$ A ID TEA5>3.0.CO;2-L.

Dodge, Y. (2008). The concise encyclopedia of statistics. Switzerland, AG: Springer.

Fadilah, F., Isti, S., Wida, T., Amarta, D., \& Prabowo, C. A. (2020). Analisis kemampuan literasi sains siswa SMA pada pembelajaran biologi menggunakan noslit. [Analysis of high school students' scientific literacy skills in learning biology using noslit]. BioEdUIN: Jurnal Program Studi Pendidikan Biologi, 10(1), 27-34. https://journal.uinsgd.ac.id/index.php/ bioeduin/article/view/8141.

Fakhriyah, F., Masfuah, S., Roysa, M., Rusilowati, A., \& Rahayu, E. S. (2017). Student's science literacy in the aspect of content science? Jurnal Pendidikan IPA Indonesia, 6(1), 81-87. https://doi. org/10.15294/jpii.v6i1.7245.

Fausan, M. M., Susilo, H., Gofur, A., Sueb, S., \& Yusop, F. D. (2021). Assessing students' prior knowledge on critical thinking skills in the biology classroom: Has it already been good? AIP Conference Proceedings, 2330(1), 30016. https://doi. org/10.1063/5.0043167.
Fives, H., Huebner, W., Birnbaum, A. S., \& Nicolich, M. (2014). Developing a measure of scientific literacy for middle school students. Science Education, 98(4), 549-580. https://doi.org/10.1002/ sce. 21115 .

Genç, M. (2015). The effect of scientific studies on students' scientific literacy and attitude. Ondokuz Mayis University Journal of Education Faculty, 34(1), 141-152. https://dergipark.org.tr/en/pub/omuefd/ issue/20280/215035.

Glazer, N. (2011). Challenges with graph interpretation: A review of the literature. Studies in Science Education, 47(2), 183210. https://doi.org/10.1080/03057267.20 11.605307.

Goldstein, J., \& Flynn, D. F. B. (2011). Integrating active learning \& quantitative skills into undergraduate introductory biology curricula. American Biology Teacher, 73(8), 454-461. https://doi. org/10.1525/abt.2011.73.8.6.

Gormally, C., Brickman, P., \& Lut, M. (2012). Developing a test of scientific literacy skills (TOSLS): Measuring undergraduates' evaluation of scientific information and arguments. CBE Life Sciences Education, 11(4), 364-377. https://doi.org/10.1187/ cbe.12-03-0026.

Gu, X., Wang, C., \& Lin, L. (2019). Examining scientific literacy through new media. Eurasia Journal of Mathematics, Science and Technology Education, 15(12), 1-14. https://doi.org/10.29333/ejmste/109948.

Hasan, R., Lukitasari, M., Utami, S., \& Anizar, A. (2019). The activeness, critical, and creative thinking skills of students in the lesson study-based inquiry and cooperative learning. Jurnal Pendidikan Biologi Indonesia, 5(1), 77-84. https:// doi.org/10.22219/jpbi.v5i1.7328.

Hestiana, H., \& Rosana, D. (2020). The effect of problem-based learning based sosioscientific issues on scientific literacy and problem-solving skills of junior 
high school students. Journal of Science Education Research, 4(1), 15-21. https:// doi.org/10.21831/jser.v4i1.34234.

Huryah, F., Sumarmin, R., \& Effendi, J. (2017). Analisis capaian literasi sains biologi siswa SMA kelas X sekota Padang. [Analysis of Biological science literacy achievement for class X senior high school students in Padang]. Jurnal Eksakta Pendidikan, 1(2), 72. https://doi.org/10.24036/jep.v1i2.70.

Indrawatiningsih, N., Purwanto, P., Rahman, A., $\&$ Sa'dijah, C. (2020). Argument mapping to improve student's mathematical argumentation skills. TEM Journal, 9(3), 1208-1212. $\quad$ https://doi.org/10.18421/ TEM93-48.

Jones, T. L., Baxter, M., \& Khanduja, V. (2013). A quick guide to survey research. Annals of the Royal College of Surgeons of England, 95(1), 5-7. https://doi.org/10.13 $\underline{08 / 003588413 X 13511609956372 .}$

Jufrida, J., Basuki, F. R., Kurniawan, W., Pangestu, M. D., \& Fitaloka, O. (2019). Scientific literacy and science learning achievement at junior high school. International Journal of Evaluation and Research in Education, 8(4), 630-636. http://doi.org/10.11591/ijere.v8i4.20312.

Kähler, J., Hahn, I., \& Köller, O. (2020). The development of early scientific literacy gaps in kindergarten children. International Journal of Science Education, 42(12), 1988-2007. https:// doi.org/10.1080/09500693.2020.180890 $\underline{8}$.

Kemendikbud RoI. (2017). Konsep literasi sains dalam Kurikulum 2013. [The concept of scientific literacy in the 2013 Curriculum]. Jakarta, Indonesia: Pusat Kurikulum dan Perbukuan.

Kothari, C. R. (2004). Research methodology: Methods and techniques. New Delhi, India: New Age International.

Kumar, K., \& Banerjee, P. (2018). Functional scientific literacy among prospective teachers: A comparative study.
International Journal of Advanced Educational Research, 3(2), 160-164. http://www.educationjournal.org/ archives/2018/vol3/issue2/3-2-12.

Lederman, N. G., Lederman, J. S., \& Antink, A. (2013). Nature of science and scientific inquiry as contexts for the learning of science and achievement of scientific literacy. International Journal of Education in Mathematics, Science and Technology, 1(3), 138-147. https:// www.ijemst.net/index.php/ijemst/article/ view/19.

Leedy, P. D., \& Ormrod, J. E. (2019). Practical research: Planning and design $\left(12^{\text {th }}\right.$ ed). Harlow, Essex: Pearson Education Limited.

Liu, X. (2009). Beyond science literacy: Science and the public. International Journal of Environmental and Science Education, 4(3), 301-311. https://files.eric.ed.gov/ fulltext/EJ884399.pdf.

Metz, A. M. (2008). Teaching statistics in biology: Using inquiry-based learning to strengthen understanding of statistical analysis in biology laboratory courses. CBE Life Sciences Education, 7(3), 317326. https://doi.org/10.1187/cbe.07-07$\underline{0046}$.

Nainggolan, V.A., Situmorang, R.P., \& Hastuti, S.P. (2021). Learning bryophyta: improving students' scientific literacy through problem-based learning. Jurnal Pendidikan Biologi Indonesia, 7(1), 7180. https://ejournal.umm.ac.id/index.php/ jpbi/article/view/15220.

Napal, M., Mendióroz-Lacambra, A. M., \& Peñalva, A. (2020). Sustainability teaching tools in the digital age. Sustainability, 12(8), 1-14. https://doi.org/10.3390/ SU12083366.

Natalina, M., \& Suryawati, E. (2019). Profil kemampuan literasi sains siswa SMA kelas $\mathrm{X}$ di kota Pekanbaru tahun ajaran 2017/2018. [Profile of science literacy ability of high school students of class $\mathrm{X}$ in Pekanbaru school year]. 
Talenta Conference Series: Science and Technology, 2(2). https://doi. org/10.32734/st.v2i2.537.

Novaristiana, R., N., Rinanto, Y., \& Ramli, M. (2019). Scientific literacy profile in biological science of high school students. Jurnal Pendidikan Biologi Indonesia, 5(1), 9-16. https://doi.org/10.22219/jpbi. v5i1.7080.

OECD. (2013). PISA 2015: Draft science framework. https://www.oecd.org/ pisa/pisaproducts/Draft $\% 20$ PISA $\% 20$ 2015\%20Science $\% 20$ Framework $\% 20$. pdf.

Okada, A. (2013). Scientific literacy in the digital age: Tools, environments, and resources for co-inquiry. European Scientific Journal, 4(12), 263-274. https://eujournal. org/index.php/esj/article/view/2479.

Osborne, Jonathan F., \& Patterson, Alexis. (2011). Scientific argument and explanation: A necessary distinction? Science Education, 95(4), 627-638. https://doi.org/10.1002/ sce. 20438 .

Podgornik, B. B., Dolničar, D., \& Glažar, S. A. (2017). Does the information literacy of university students depend on their scientific literacy? Eurasia Journal of Mathematics, Science and Technology Education, 13(7), 3869-3891. https://doi. org/10.12973/eurasia.2017.00762a.

Pratiwi, S. N., Cari, C., \& Aminah, N. S. (2019). Pembelajaran IPA Abad 21 dengan literasi sains siswa. [21st century science learning with student science literacy]. Jurnal Materi dan Pembelajaran Fisika (JMPF), 9(1), 34-42. https://jurnal.uns.ac.id/jmpf/ article/view/31612.

Rahmadani, Y., Fitakurahmah, N., Fungky, N., Prihatin, R., Majid, Q., \& Prayitno, B. A. (2018). Profil keterampilan literasi sains siswa di salah satu sekolah swasta di Karanganyar. [Profile of students' scientific literacy skills at a private school in Karanganyar]. Jurnal Pendidikan Biologi, 7(3), 183-190. https://doi. org/10.24114/jpb.v7i3.10123.
Ristanto, R. H., Zubaidah, S., Amin, M., \& Rohman, F. (2017). Scientific literacy of students learned through guided inquiry. International Journal of Research and Review. 4(5), 23-30. https://www. ijrrjournal.com/IJRR_Vol.4_Issue.5 May2017/Abstract IJRR004.html.

Sekaran, U. (2003). Research methods for business: A skill-building approach. New York, NY: John Wiley \& Sons.

Shaffer, J. F., Ferguson, J., \& Denaro, K. (2019). Use of the test of scientific literacy skills reveals that fundamental literacy is an important contributor to scientific literacy. CBE Life Sciences Education, 18(3), 1-10. https://doi.org/10.1187/cbe.18-120238 .

Sharma, R., \& Sharma, L. R. (2017). Scientific literacy education: Reflections from Fiji. Asia-Pacific Forum on Science Learning and Teaching, 18(2), 1-13. https://www. eduhk.hk/apfslt/v18 issue2/sharma/ index.htm.

UNEP (United Nations Environment Programme). (2012). 21 Issues for the 21st century: Result of the UNEP foresight process on emerging environmental issues. Kenya: Author.

Wicaksono, R. S., Susilo, H., \& Sueb, S. (2019). Implementation of problembased learning combined with think pair share in enhancing students' scientific literacy and communication skill through teaching biology in English course peerteaching. Journal of Physics: Conference Series, 1227(1), 1-8. https://doi. org/10.1088/1742-6596/1227/1/012005.

Widayoko, A., Femilia, P. S., Lesmono, A. D., Sudjatmi, H., Prastiwi, V. D., \& Munfarikha, N. (2019). Description of Students' scientific literacy competencies on the scientific issue of flat earth theory. Anatolian Journal of Education, 4(2), 31-38. https://doi.org/10.29333/ aje.2019.424a. 
Winarni, E. W., \& Purwandari, E. P. (2020). Project-based learning to improve scientific literacy for primary education postgraduate students in science subject. Jurnal Prima Edukasia, 8(1), 66-76. https://doi.org/10.21831/jpe.v8i1.30618.

Yore, L. D., Pimm, D., \& Tuan, H.-L. (2007). The literacy component of mathematical and scientific literacy. International Journal of Science and Mathematics Education, 5(4), 559-589. https://doi.org/10.1007/ s10763-007-9089-4.

Yuenyong, C. (2013). Enhancing scientific literacy in Thailand. Global Studies of Childhood, 3(1), 86-98. https://doi. org/10.2304/gsch.2013.3.1.86. 